\title{
Freeze-etching and Biochemical Analysis of Human Fetal Erythrocyte Membranes
}

\author{
JOSEPH KURANTSIN-MILLS ${ }^{\prime}$ AND LAWRENCE S. LESSIN \\ Division of Hematology and Oncology and Department of Physiology, The George Washington University, \\ Medical Center, Washington, D. C. 20037
}

\section{Summary}

In order to test the hypothesis that there are ultrastructural and supramolecular differences between fetal and adult erythrocyte membranes that are manifested in their functional characteristics, the cells were studied by freeze-etching and transmission microscopy and biochemical methods. Freeze-etching and transmission electron microscopy of fetal erythrocyte membranes showed that the protoplasmic and exoplasmic fracture faces have $\mathbf{2 4 \%}$ and $\mathbf{4 5 \%}$ greater intramembrane particles respectively compared to adult cells $(p<0.01)$. The apparent diameters of the intramembrane particles estimated on the exoplasmic fracture face averaged as follows: $4.84,7.74,11.42$, and $15.64 \mathrm{~nm}$, which are similar to estimates in adult cell membranes, suggesting similar dimensions for the presumptive glycoprotein structures in the fluid mosaic complex of the cell membranes. The average total cholesterol, phospholipid, and protein content per fetal erythrocyte ghost as well as ratios of protein/lipid, protein/ cholesterol, and protein/phospholipids were all significantly greater than in the adult ghost $(p<0.01)$. Analysis of fetal and adult ghost proteins by sodium dodecyl sulfate-polyacrylamide gel electrophoresis showed similar qualitative and quantitative polypeptide and glycopeptide bands except for the intense appearance of bands 4.5 and 8 in the fetal samples. Polypeptide chains per ghost membrane were significantly greater in fetal ghosts than in adult ghosts. However, the molar ratios of the major polypeptides relative to band 3 , the predominant protein in the ghost membrane, are comparable for the two cell types except for bands 4.5 and 8 . These findings suggest that the molecular characteristics of the erythroid plasma membrane vary with the developmental age.

\section{Abbreviations}

RBC, red blood cell

IMPs, intramembrane particles

$\mathrm{PF}$, protoplasmic fracture face

$\mathrm{EF}$, exoplasmic fracture face

SDS-PAGE, sodium dodecyl sulfate-polyacrylamide gel electrophoresis

Hb, hemoglobin

PAS, periodic acid-Schiff reagent

Human fetal RBCs possess several characteristics that are unique to the developmental stage of the fetus. Most erythrocyte

Received January 13, 1981; accepted March 19, 1984.

Correspondence may be addressed to Dr. Lawrence S. Lessin, George Washington University Medical Center, 2300 I Street, Washington, D. C. 20037.

This work was supported for by the World Health Organization (Fellowship 7310-344-6201-6)

'Present address: Department of Biochemistry, Research Division, Hospital for Sick Children, 555 University Avenue, Toronto, Ontario, Canada M5G 1X8. glycolytic enzymes exhibit increased activities in fetal RBCs (13, 30). Enolase and phosphoglycerate kinase, for example, have disproportionately high activities, whereas phosphofructokinase is relatively deficient (29). Immunologically, the Lewis system A and $\mathrm{B}$ antigens are incompletely expressed, and the I antigen is also weakly developed (26). RBC membrane permeability to water, glycerol, and thiourea is significantly less in fetal cells (3, $28,41)$. Interference contrast microscopy shows a high percentage of pits or craters on the fetal RBC surface (16), which appear in the transmission electron microscope as vacuoles immediately beneath the cell membrane (4). Other studies (14) have demonstrated significant vesiculation $(25.5 \%)$ in circulating RBCs of neonates compared to the mother's (5.5\%). Furthermore, Schekman and Singer (33) have shown that concanavalin A, but not succinyl-concanavalin A, is engulfed by endocytosis in fetal RBCs, resulting in intracellular vesiculation. No such response was noted for adult cells. The objective of the present studies is to test the hypothesis that the functional differences of fetal erythrocyte membranes are reflected in their ultrastructural and macromolecular characteristics. Abstracts of this study have been published elsewhere $(19,20)$.

\section{MATERIALS AND METHODS}

Source of blood samples. Human fetal blood samples were withdrawn from the placental side of the umbilical cord following normal delivery of human fetuses. Fetal blood was from normal, healthy pregnancies and the neonates were full-term infants. Adult blood was donated by healthy laboratory personnel who were free from any hematologic abnormalities. Analysis of red cell indices and reticulocyte counts showed typical values as reported in the literature (30) (data not shown). Appropriate informed consent was obtained for this study.

Freeze-etching and transmission electron microscopy. Freezeetching of erythrocyte membranes was carried out in a Balzers 300 Ultrahigh vacuum device by the method of Moor and Muhlethaler (27). The washed erythrocytes were cryoprotected in $25-30 \%$ glycerol medium. Droplets of thick cell suspension were then pipetted onto gold discs and frozen in liquid Freon (dichlorodifluoromethane) $\left(-150^{\circ} \mathrm{C}\right)$ and then stored in liquid nitrogen. The frozen specimens were then transferred onto the freeze-etching microtome stage and the chamber was evacuated to $10^{-6}$ torr. The specimen was fractured by a single stroke or multiple chips using the cold $\left(-100^{\circ} \mathrm{C}\right)$ microtome knife, and then sublimated (deep-etched) for about $2 \mathrm{~min}$. A replica was obtained by evaporating platinum and carbon onto the fractured surface for $5 \mathrm{sec}$ at a $45^{\circ}$ angle, followed by carbon coating for $10 \mathrm{sec}$. The specimen was removed from the device, the replica was floated in buffered $30 \%$ glycerol or water, cleaned of cellular debris in $70 \%$ sulfuric acid $(1-2 \mathrm{~h})$, in dilute sodium hypochlorite (20-30 $\mathrm{min}$ ) and distilled water (30 min). Replicas obtained were placed on 100-mesh copper grids and examined in an AEI 
EM801 or JEOL JEM 100B electron microscope. Images were photographed at $\times 10,000-40,000$. Higher magnification was obtained during printing of the negatives.

Quantitation of intramembrane particle size and density. Micrographs of the flat areas of replicas were used for counting of IMPs and the measurement of their sizes. Negatives were printed at a final magnification of $\times 100,000$ for both particle size and counts. The accuracy of the magnification was checked periodically with a grating replica standard (E.F. Fullam Co., Schenectady, NY). A standard morphometric grid pattern (designed from a regular centimeter graph paper, $21.6 \times 27.9 \mathrm{~cm})(1$ square $=1$ $\mathrm{cm}^{2}$ ) with $X$ and $Y$ coordinates was placed on the photographic paper during the enlargement phase of the printing. IMPs were counted on positives, locating their $X$ - $Y$ coordinates to eliminate the possibility of counting or measuring the same particle twice. The size of the intramembrane particles was measured with a calibrated ocular micrometer fitted to a dissecting microscope. They were measured across their "diameters" in a direction perpendicular to the direction of shadowing to the nearest 0.1 $\mathrm{mm}$. Only particles on the EF face were used for the particle size analysis because of their individual distinctness. Several hundreds of IMPs were counted for both the PF and EF faces of fetal and adult specimens (see "Results") using six and 10 test fields (21.6 $\times 27.9 \mathrm{~cm}$ ) for both specimens, respectively. Specimens were obtained from the cells of two fetal and six adult donors. Because of technical difficulties in obtaining the same size for the different test fields, a few whose dimensions were less than stated above were also included in the counting and sizing of IMPs. The IMP estimates from the respective fracture faces were then pooled from all the test fields for statistical evaluation. Intramembrane particle size measured from freeze-fracture micrographs is probably related to the size of shadowed membrane proteins. Therefore, relative changes in particle size determined by this method probably reflect relative size of the glycoproteins. Accordingly, a correction suggested by Lessin et al. (22) was used in the calculation to account for the distortion produced by the replication process.

Preparation of "hemoglobin-free" erythrocyte membranes. Hemoglobin-free erythrocyte ghost membranes were prepared at $4^{\circ} \mathrm{C}$ as described by Dodge et al. (8). In order to compare the amount of residual hemoglobin in fetal and adult erythrocyte ghost, washing conditions were maintained identically, using stroma to washing buffer ratio of 1:50. Residual hemoglobulin in the ghost was estimated by polyacrylamide gel electrophoresis as described below.

Determination of total lipid, cholesterol, and phospholipid. Total membrane lipids were extracted from thoroughly washed erythrocytes using isopropanol:chloroform $(11: 7, \mathrm{v} / \mathrm{v})$ mixture according to the method of Rose and Oklander (32). The extract was evaporated to dryness under gaseous nitrogen and redissolved in isopropanol. The lipid solution was then divided into three fractions and used for the separate determination of total lipid, cholesterol, and lipid phosphorus.

The isopropanol extract for cholesterol assay was treated with Zeolite mixture to remove phospholipids, glucose, bilirubin, and certain other substances which interfere with the sterol determination. The supernatant extract was then mixed with Liebermann-Bruchard reagent, and the concentration of cholesterol was determined colorimetrically at $620 \mathrm{~nm}$ by the method of Abdell et al. (1) using the Autoanalyzer II (Technicon Instruments Corp., Tarrytown, NY).

Total lipid was determined gravimetrically after evaporation of the solvent and drying the test tube overnight in a desiccator containing anhydrous $\mathrm{CuSO}_{4}$.

Lipid phosphorus was determined on the isopropanol extract by (i) evaporating the solvent to dryness under nitrogen atmosphere, (ii) preparing a Folch extraction mixture (chloroform:methanol, 2:1, v/v) (11), (iii) digestion of the phospholipid to inorganic phosphate in $19 \mathrm{M} \mathrm{H}_{2} \mathrm{SO}_{4}$ at 150 to $160^{\circ} \mathrm{C}$ and discoloration of the digested mixture with $30 \% \mathrm{H}_{2} \mathrm{O}_{2}$, and (iv) analysis of the inorganic phosphate by the method of Bartlet (2).
Assay of protein content of ghost membranes. Protein content of the hemoglobin-free ghost membranes was assayed by the method of Lowry et al. (23) using bovine serum albumin as a standard. Membrane preparations were dissolved in $0.06 \%$ SDS in 20 mosm phosphate-buffered saline, $\mathrm{pH}$ 7.6. The standard albumin solutions contained the same concentration of SDS.

Sodium dodecyl sulfate-polyacrylamide gel electrophoretic analysis of membrane proteins. The general procedure was that of Fairbanks et al. (10). Gel polymerization followed the chemical procedure of Davis (7). Concentrated stock solutions and their order and proportions for mixing into the final form were the same as described elsewhere (10). Molecular weight markers for the calibration of the gels were horse heart cytochrome $c$ $(12,500)$, bovine pancreas chymotrypsinogen $\mathrm{A}(24,700)$, hen egg albumin $(45,000)$, bovine serum albumin $(68,000)$, and rabbit muscle aldolase monomer $(40,000)$ (Boehringer Mannheim GmbH Biochemica, Indianapolis, IN). Densitometry was performed at $560 \mathrm{~nm}$ on the stained gels using Beckman Acta III Spectrophotometer with split width of $0.1 \mathrm{~mm}$.

Determination of residual hemoglobin in ghosts. The small quantities of hemoglobin remaining in ghost membranes were determined by polyacrylamide gel electrophoresis in SDS. The gels were stained with Coomassie brilliant blue and the intensity of the protein (hemoglobin monomer) was determined by densitometry. The proportion of hemoglobin monomer was calculated as percentage of the area under the densitometric scans and the amount of protein it represents calculated from the total protein per ghost. Therefore, the absolute hemoglobin per ghost is given by: $\mathrm{mg}$ of $\mathrm{Hb} /$ ghost $=($ protein/ghost $) \times(\% \mathrm{Hb}$ protein $)$ and moles of $\mathrm{Hb} / \mathrm{ghost}=\mathrm{mg}$ of $\mathrm{Hb} / \mathrm{ghost} / 64,000$ daltons, where protein per ghost was from protein assay on a fixed volume of ghosts and the mean corpuscular volume of the cells. Ghost hemoglobin was also expressed as a percentage of the mean corpuscular hemoglobin.

Statistical methods. Statistical analysis of data utilized Student's $t$ test performed on a Canon 167P-11-1614P programmable calculator (6).

\section{RESULTS}

Observation on freeze-etched intact erythrocyte membranes. Freeze-etch electron micrographs of the replicas of intact erythrocyte membranes revealed (a) a granular and fibrillar cytoplasmic space, (b) split bilayer halves or lamellae of half-membranes studded with particles of varying size, and (c) an extracellular glycerol-buffer eutectic which appeared uniformly rugged (Fig. 1).

The split "half-membranes" or "bilayer halves" contain the numerous IMPs. The IMPs on the PF appear as relatively homogeneous in size and are closely arrayed. By contrast, IMPs on the EF are heterogeneous in size and shape. Besides the heterogeneity of the particle population on the EF, there are granulofilamentous and fibrillar structures on this face of the cell membranes (Fig. 1 $B$ ). Similar structures have been described previously for adult cell membranes (38), and confirmed in this study. However, a closer inspection of these fibrillar structures on the EF of fetal membrane suggest that (a) they are more numerous, (b) some are in contact with IMPs, (c) they have variable sizes and some appear to emerge or be buried within the relatively smooth ground matrix, (d) in some areas of the micrograph the filaments appear reticular, and (e) in other areas they extend to or from the juxtacytoplasmic phase of the bilayer. The filaments measure approximately 5.0 to $8.0 \mathrm{~nm}$ in diameter, and 50 to $70 \mathrm{~nm}$ in length. The lack of complementary component structures or grooves on the PF of the membrane has made it difficult to interpret these structures. Figure $1 C$ illustrates a micrograph of the fracture faces of adult erythrocyte membranes compared to that of the fetal erythrocyte (Fig. 1, $A$ and $B$ ).

Quantitation of intramembrane particles. Quantitation of particle distribution of the membrane PF and EF of fetal and adult red cells indicate different particle density counts for the two cell 

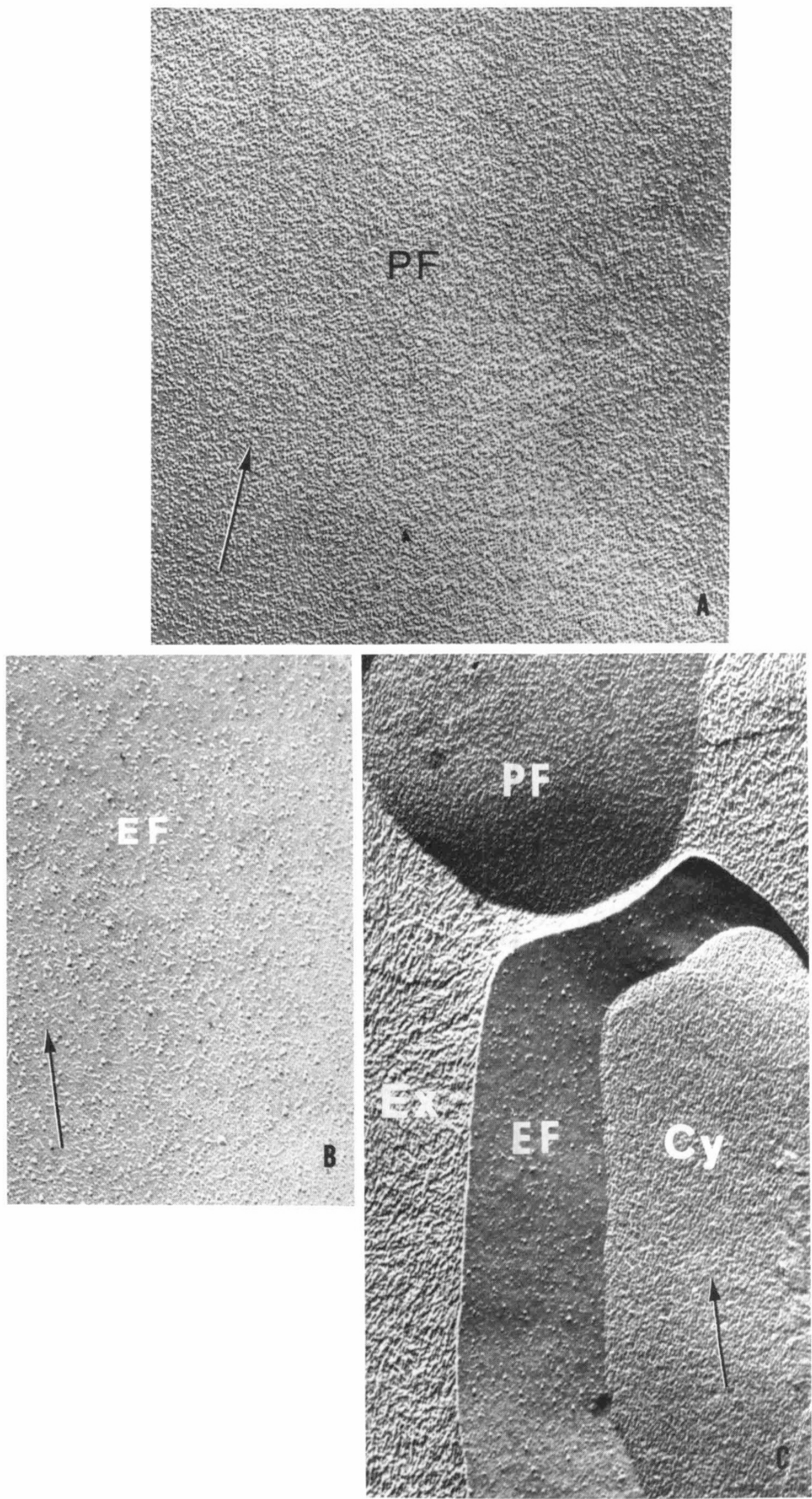

Fig. 1. Freeze-etched electron micrographs. $A$ and $B$, fetal erythrocyte membranes showing the PF and EF of the bilayer. The PF reveals the dense, almost uniformly sized intramembrane particles. The EF reveals the heterogeneous intramembrane particles and several fibrillar and filamentous structures embedded within the ground substance. Magnification: $A, \times 71,400 ; B, \times 76,500$. Arrow indicates the direction of shadowing. $C$, micrographs of membranes of adult erythrocytes showing the fractured halves of the lipid bilayer studded with intramembrane particles on the $\mathrm{PF}$ and EF. The cytoplasmic phase containing hemoglobin complexes $(C y)$ and the extracellular glycerol-buffer eutectic $(E x)$ are also shown. Magnification: $\times 40,800$. Arrow indicates the direction of shadowing. 


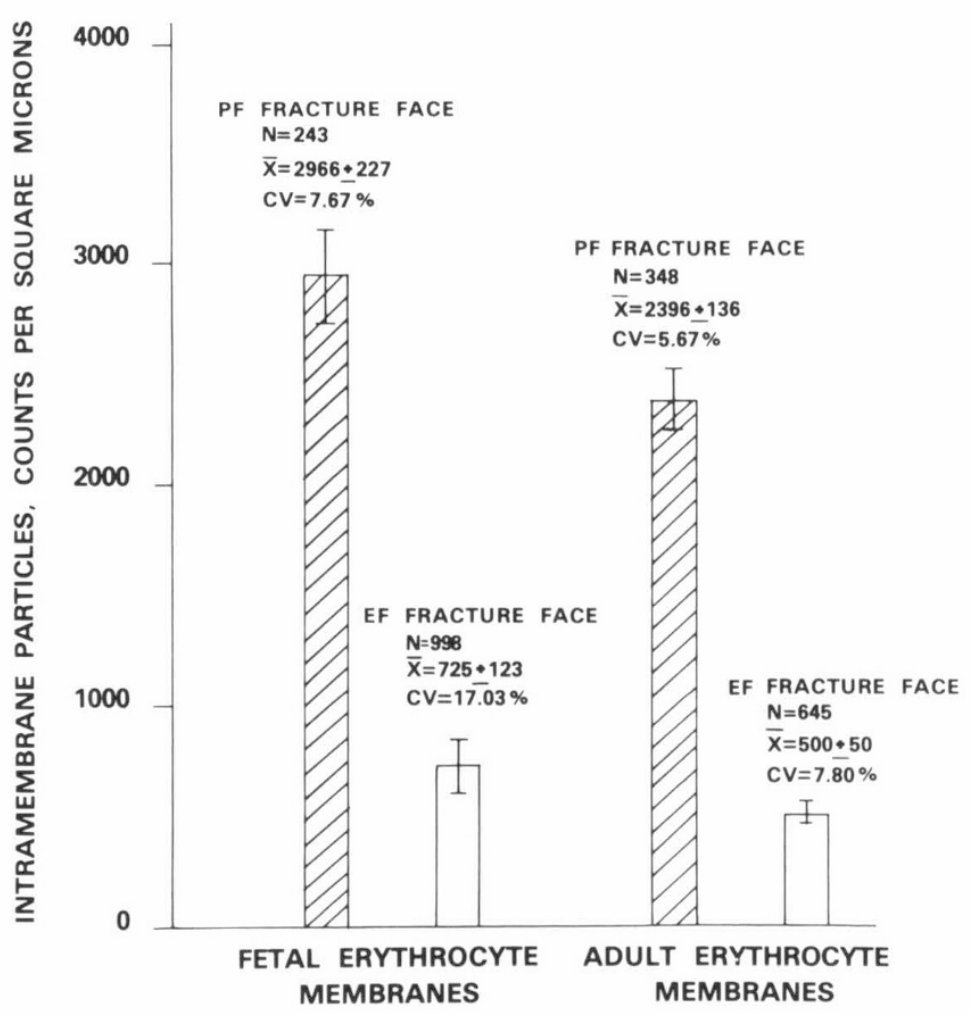

Fig. 2. Histogram comparing the distribution of IMPs per $\mu \mathrm{m}^{2}$ of the fractured faces of erythrocyte membrane. $N=$ number of IMPs counted. $C V$, coefficient of variation; IMP density expressed as mean $\pm \mathrm{SD}$.

types. Figure 2 is a histogram comparing the mean IMP density on the PF and EF of the cell types. The PF and EF of fetal cells have 24 and $45 \%$ greater IMPs, respectively, compared to adult cells $(p<0.001)$. Computation of particles per cell surface also shows that fetal cell membranes have greater numbers of IMPs per cell surface (Table 1). The latter is based on the microscopic estimation that the mean surface area of adult cells at physiological $\mathrm{pH}$ and osmolality is approximately $135 \mu \mathrm{m}^{2}(9,35)$, and that for fetal erythrocytes is $170 \mu \mathrm{m}^{2}(5)$.

Because of the wide range of distribution of the diameters of IMPs estimated on the EF, they were arbitrarily classified into the ranges 4.0 to $5.9,6.0$ to $9.9,10.0$ to 13.9 , and 14.0 to 17.9 $\mathrm{nm}$ for the purpose of comparing fetal and adult membranes. Few IMPs, less than $1 \%$ of the total, had diameters exceeding $18.0 \mathrm{~nm}$. These were not considered with the above categories. The corrected diameter of the particles on the EF face were averaged as follows, respectively: fetal membranes, $4.84 \pm 0.001$, $7.74 \pm 1.17,11.42 \pm 0.99$, and $15.64 \pm 0.84$; adult membranes, $4.87 \pm 0.11,8.06 \pm 1.15,11.84 \pm 1.12$, and $16.15 \pm 0.90$. No significant statistical difference was noted between adult and fetal specimens. Diameters of particles on the PF was not determined because of the imprecision underlying such estimates, as described above.

Since IMPs are integral proteins, as the evidence suggests, it is relevant to relate them to the cell surface area. A particle estimated on the EF may occupy an area of $\pi r^{2}$ in the plane of the membrane, where $r$ is the radius of the IMP. The IMPs per cell of each of the categories above were then evaluated, and the total area in the plane of the membrane was calculated. Summation of the membrane area occupied by IMPs in all categories yielded the area of all IMPs of the EF face in the plane of the membrane (i.e. $\sum \pi r^{2} \times$ total IMPs in EF). For fetal cell membranes, the total IMPs may occupy an area in the EF of approximately 4.07 $\times 10^{7} \mathrm{~nm}^{2}$, and for adult cell membranes $2.24 \times 10^{7} \mathrm{~nm}^{2}$. Expressing these figures as percentages of the cell surface area give the following results: fetal cells, $\left(4.07 \times 10^{7} \mathrm{~nm}^{2} / 1.70 \times\right.$ $\left.10^{8} \mathrm{~nm}^{2}\right) \cdot 100=23.9 \%$; adult cells, $\left(2.24 \times 10^{7} \mathrm{~nm}^{2} / 1.35 \times\right.$ $\left.10^{8} \mathrm{~nm}^{2}\right) \cdot 100=16.6 \%$. Considering the limitations of these
Table 1. Distribution of intramembrane particles in human fetal and adult erythrocytes

\begin{tabular}{|c|c|c|c|c|}
\hline \multirow[b]{2}{*}{$\begin{array}{l}\text { Membrane } \\
\text { fractured face }\end{array}$} & \multirow[b]{2}{*}{$\begin{array}{c}\text { Fetal } \\
\text { erythrocytes }\end{array}$} & \multirow[b]{2}{*}{$\begin{array}{c}\text { Adult } \\
\text { erythrocytes }\end{array}$} & \multicolumn{2}{|c|}{ Fetal $v s$. adult } \\
\hline & & & $\begin{array}{c}\% \\
\text { Change }\end{array}$ & $p$ value \\
\hline $\mathrm{PF}$ & $\begin{array}{c}2,966 \pm 227 \\
\left(\text { per } \mu \mathrm{m}^{2}\right)\end{array}$ & $\begin{array}{l}2,396 \pm 136 \\
\left(\text { per } \mu \mathrm{m}^{2}\right)\end{array}$ & $\sim 24 \uparrow$ & $<0.01$ \\
\hline $\mathrm{EF}$ & $\begin{array}{l}725 \pm 123 \\
\left(\text { per } \mu \mathrm{m}^{2}\right)\end{array}$ & $\begin{array}{l}500 \pm 50 \\
\left(\operatorname{per} \mu \mathrm{m}^{2}\right)\end{array}$ & $\sim 45 \uparrow$ & $<0.01$ \\
\hline $\begin{array}{l}\text { Membrane surface } \\
\text { area }\end{array}$ & $170 \mu \mathrm{m}^{2 *}$ & $135 \mu \mathrm{m}^{2} \dagger$ & $\sim 26 \uparrow$ & $<0.01$ \\
\hline $\begin{array}{l}\text { Number of IMPs on } \\
\text { PF/cell }\end{array}$ & $505,000 \pm 10 \%$ & $325,000 \pm 5 \%$ & $\sim 55 \uparrow$ & $<0.01$ \\
\hline $\begin{array}{l}\text { Number of IMPs on } \\
\mathrm{EF} / \text { cell }\end{array}$ & $123,000 \pm 15 \%$ & $67,500 \pm 10 \%$ & $\sim 82 \uparrow$ & $<0.01$ \\
\hline Total IMPs/cell & $628,000 \pm 10 \%$ & $392,500 \pm 5 \%$ & $\sim 60 \uparrow$ & $<0.01$ \\
\hline
\end{tabular}

${ }^{*}$ From Ref. 5.

† From Refs. 9 and 35.

estimates, the data only suggest that the relative proportions of IMPs on the EF of fetal and adult erythrocyte membranes are different, and has no relation on absolute areas of the bilayer occupied by IMPs. Similar calculations were attempted for IMPs on the PF; however, because of the difficulties of estimating their "diameters," the results are not included in this report.

Lipid and protein content of fetal erythrocyte ghost membranes. Determinations of total lipids, phospholipids, cholesterol, and proteins of erythrocyte ghost membranes are shown in Table 2. Significant differences $(p<0.01)$ for fetal and adult membranes were noted when the data were expressed as milligrams per cell as previously reported (30). Comparison of the protein lipid phosphorus ratios also show greater values for fetal ghosts (Table 2).

Residual hemoglobin of ghost membranes. Analysis of membrane hemoglobin by SDS-PAGE and quantitative densitometry showed that fetal ghosts contained greater hemoglobin than adult 
ghosts. Fetal ghosts contained $0.14 \times 10^{-13} \mathrm{~g}$ hemoglobin protein/ghost $\left(2.50 \times 10^{-19} \mathrm{~mol} /\right.$ ghost $)$ or about $0.39 \%$ of the mean corpuscular hemoglobin. Adult ghosts, on the other hand, contained $0.087 \times 10^{-13} \mathrm{~g}$ hemoglobin protein/ghost $\left(1.36 \times 10^{-19}\right.$ $\mathrm{mol} /$ ghost) or approximately $0.30 \%$ of the mean corpuscular hemoglobin $(n=13, p<0.1)$. This method of determining ghost hemoglobin, unlike others $(8,36,37)$, has the added advantage that the residual hemoglobin is analyzed in the same experiment as the ghost membrane proteins.

Electrophoretic fractionation of ghost proteins. Fractionation of ghost proteins by analytical polyacrylamide gel electrophoresis, containing $0.5 \%$ SDS demonstrated a consistent pattern of Coomassie blue-stained protein bands with a characteristic distribution between the anodal and cathodal ends of the gel. Figure 3 illustrates the results obtained on ghosts of fetal erythrocytes. Adult control gel electropherograms revealed similar distribution of the protein and glycoprotein bands when the same amount of proteins, as with the fetal ghosts, were electrophoresed. The Coomassie blue-stained gels consisted of about eight well resolved protein bands which have been labeled according to the system originally proposed by Fairbanks et al. (10) and Steck (34). There were also several minor bands which could only be seen when the gels were illuminated from below and scrutinized in detail. The intensity of these minor bands was variable and so the total number of protein bands may be 20 to 30 . The intensity of the minor bands was affected by changes in the conditions of the electrophoresis. The intensity of the bands between 2 and 3 and 4.2 and 5 appeared to be sensitive to the preparation of membrane, namely ratio of lysing buffer to cells, number of times the ghosts were washed, presence or absence of the "cream-colored button," and amount of protein loaded on the gels. The concentration of SDS in the reduction reaction also influenced the resolution of these bands. Band 4.5, for example, appeared as two distinct bands embedded in a rather diffuse background which tended to obscure its distinctness. This is evident from the densitometric scans (data not shown). Band 4 appeared as a doublet when the SDS concentration of the gels and the electrophoresis buffer was $0.5 \%$ or less. Bands 7 and 8 were as intense as shown in Figure 3 in fractionations with $0.5 \%$ or less SDS in the gels and buffer. The intensity of the globin band was directly related to the number of times the ghosts were washed in suspension. When the protocol for membrane preparation described above was adhered to, the intensity of all bands was consistent and globin band intensity was relatively faint and constant.

Table 2. Comparison of protein and lipid content and ratios in fetal and adult erythrocyte membranes*

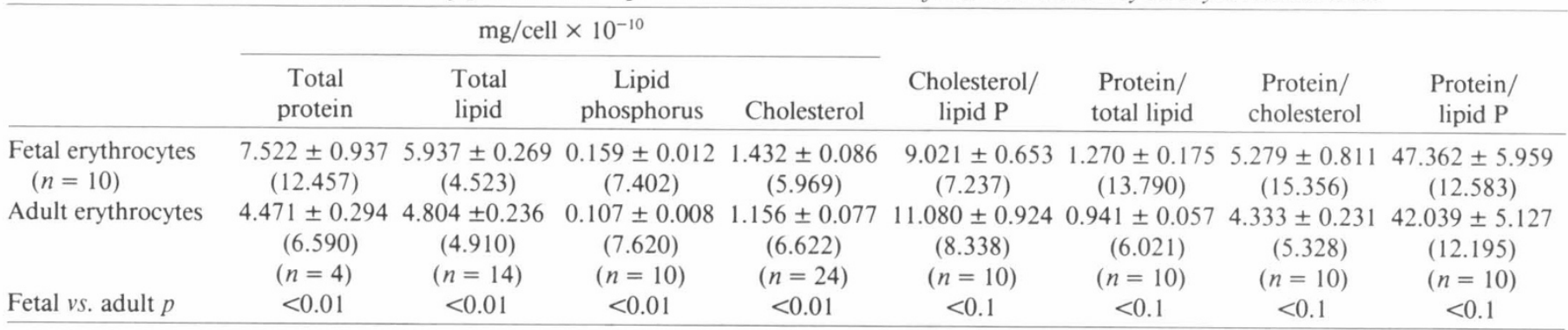

* Values are mean \pm SD. Numbers in parentheses, per cent coefficient of variation.

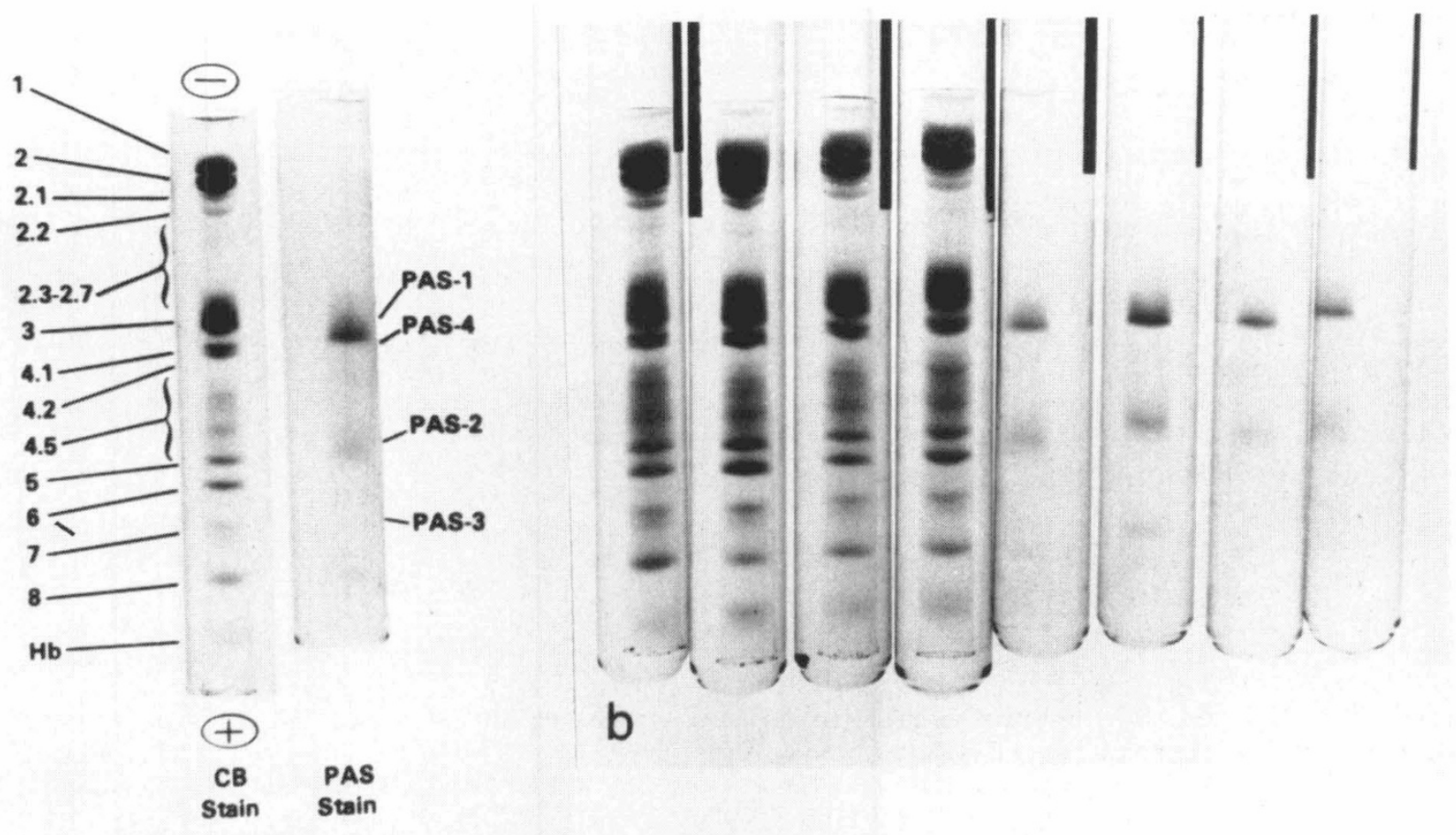

a

Fig. 3. Electropherograms of adult $(a)$ and fetal $(b)$ erythrocyte ghost proteins fractionated in SDS-polyacrylamide gels. Ghosts were dissolved in $1 \%$ SDS, $30 \mathrm{mM}$ dithiothreitol, and buffer, incubated at $37^{\circ} \mathrm{C}, 45 \mathrm{~min}$, and electrophoresed as described in "Materials and Methods." 30 (Coomassie blue stains) and $90 \mu \mathrm{g}$ (PAS stains) of ghost protein were loaded on each gel for the analysis of polypeptides and glycopeptides, respectively. The gels were stained with Coomassie blue $(C B)$ for the polypeptides and PAS for the glycopeptides. 
The glycosylated proteins are made visible by the PAS staining technique (Figure 3). The three major PAS-positive bands were designated PAS-1, PAS-2, and PAS-3 according to the nomenclature of Fairbanks et al. (10). A fourth rather faint band, migrating between PAS- 1 and PAS-2, was found in all membrane preparations. It was most apparent in heavily overloaded gels and showed variable distinctness among ghosts of different individuals, but the latter aspect was not studied any further.

Quantitative densitometry. Quantitative densitometry of the Coomassie blue-stained gels at $560 \mathrm{~nm}$ showed that the most distinctly stained bands, $1,2,3,4.1,4.2,5,6,7$, and 8 , comprise over $75 \%$ of the total integrated intensity of the band areas (Table 3 ). Differences between the proportions of the various protein bands were not statistically significant among the fetal and adult membrane proteins, except for differences in bands $4.5,8$, and globin.

The gels stained for polysaccharides with PAS stain and scanned at $560 \mathrm{~nm}$ show the relative abundance of PAS-1, PAS2 , PAS-3, and PAS-4 in the protein preparation (Table 3). No significant differences were noted between fetal and adult sialoglycoprotein bands. PAS- 1 and PAS-2 contain approximately $75 \%$ of the stain intensity.

Calculations based on the amount of protein per ghost, the relative abundance of Coomassie blue-stained proteins in the gels, and the number of molecules per mol of protein $(6.023 \times$ $\left.10^{23}\right)^{\circ}$ allowed estimation of the number of polypeptide chains per ghost for the major polypeptide bands (Table 3). Despite the differences in the number of polypeptide chains per ghost between fetal and adult samples, the molar ratios of the polypeptides are of the same magnitude except for bands 4.5 and 8 . The molar ratios have been estimated relative to band 3 , which is the most abundant polypeptide found in the red cell ghosts.

\section{DISCUSSION}

Transmission electron microscopy of replicas of freeze-etched fetal erythrocyte membranes revealed hydrophobic domains of the lipid bilayer studded with IMPs of varying diameters. Independent assessment of IMP density revealed that the PF and EF of fetal RBC membranes have 24 and $45 \%$ greater IMPs, respectively, compared to the adult cells. Accordingly, the estimated IMP density per cell, based on the cell surface area, is significantly greater in fetal cells $(p<0.01)$. Kelley and Skipper (17) have also reported that membranes of human embryo fibroblasts exhibit more particles on their PF than corresponding membrane halves from aged cells. In contrast, the EF of cells from aged individuals have significantly more particles than corresponding faces of cell membranes from younger individuals. Other studies (15) on developing corneal fibroblast cell membrane show that IMP density on the PF decreases from 756 to $534 / \mu \mathrm{m}^{2}$ from day 6 to day 14 . Furthermore, the cell membranes of the terminally differentiated, highly compacted fibroblasts are rich in IMPs $\left(13,000 / \mu \mathrm{m}^{2}\right)$. Taken together, these observations $(15,17)$ suggest that cell membranes alter their ultrastructural properties during aging. The apparent diameters of the IMPs estimated on the EF face are the same in both fetal and adult erythrocyte membranes. Previous studies $(21,25)$ have estimated IMP diameters on the fractured faces as 8.0 to $10.0 \mathrm{~nm}$. However, we have observed great variability in IMP sizes, and statistical evaluation of the data confirm this viewpoint. There are also distinct granulofibrillar structures in the EF in most of the membranes. Since there are no complementary grooves on the PF, McNutt (25) suggests that the filamentous structures on the $\mathrm{EF}$ arise by plastic deformation of cytoplasmic filaments which are firmly attached to the plasma membrane. Experimental evidence supporting this view comes from the work of Willison (40), who noted that the amount of plastic deformation of a protein depends on the orientation of its bonding forces relative to the fracture plane.

The higher average proportion of total lipid, cholesterol, phospholipid, and total protein per fetal erythrocyte correlates well with the greater mean corpuscular volume. Other investigators (12) who have fractionated the phospholipids of fetal and adult erythrocytes have demonstrated relatively more sphingomyelin, combined phosphatidylserine and phosphatidylinositol, and less

Table 3. Some characteristics of the major polypeptides and glycoproteins of fetal and adult red cell ghosts

\begin{tabular}{|c|c|c|c|c|c|c|c|}
\hline \multirow[b]{2}{*}{$\begin{array}{l}\text { Polypeptide } \\
\text { component }\end{array}$} & \multirow[b]{2}{*}{$\begin{array}{l}\text { Molecular } \\
\text { weight } \\
\text { (D) }\end{array}$} & \multicolumn{2}{|c|}{ Fetal ghost polypeptides } & \multicolumn{2}{|c|}{ Adult ghost polypeptides } & \multirow{2}{*}{$\begin{array}{l}\text { Fetal ghost } \\
\text { polypep- } \\
\text { tides } \\
\text { molar ratios } \\
\text { relative to } \\
\text { band } 3 \\
\text { (mean) }\end{array}$} & \multirow{2}{*}{$\begin{array}{l}\text { Adult ghost } \\
\text { polypeptide } \\
\text { molar ratios } \\
\text { relative to } \\
\text { band } 3 \\
\text { (mean) }\end{array}$} \\
\hline & & $\begin{array}{c}\% \text { of stained } \\
\text { protein }( \pm S D)\end{array}$ & $\begin{array}{l}\text { Polypeptides/ } \\
\text { ghosts* } \\
\left(\times 10^{5}\right)\end{array}$ & $\begin{array}{c}\% \text { of stained } \\
\text { protein }( \pm S D)\end{array}$ & $\begin{array}{c}\text { Polypeptides/ } \\
\text { ghost } \dagger \\
\left(\times 10^{5}\right)\end{array}$ & & \\
\hline 1 & $250,000 \pm 10,000$ & $12.53 \pm 1.18$ & 2.27 & $12.33 \pm 0.50$ & 1.33 & 0.22 & 0.22 \\
\hline $2 \ddagger$ & $220,000 \pm 10,000$ & $12.74 \pm 1.37$ & 2.63 & $11.31 \pm 1.04$ & 1.40 & 0.25 & 0.23 \\
\hline $2.3-2.7$ & & $2.38 \pm 0.59$ & & & & & \\
\hline 3 & $95,000 \pm 5,000$ & $21.72 \pm 1.19$ & 10.34 & $21.17 \pm 0.42$ & 6.03 & 1.00 & 1.00 \\
\hline $4.1-4.2$ & $79,000-72,000 \pm 2,000$ & $7.96 \pm 0.60$ & 4.58 & $8.71 \pm 0.74$ & 3.00 & 0.44 & 0.50 \\
\hline $\begin{array}{l}4.5 \mathrm{~A} \\
4.5 \mathrm{~B}\end{array}$ & $65,000 \pm 2,000$ & $\begin{array}{l}7.74 \pm 1.14 \\
6.98 \pm 0.98\end{array}$ & 10.21 & $\begin{array}{l}5.62 \pm 0.30 \\
5.76 \pm 0.19\end{array}$ & 4.70 & 0.99 & 0.78 \\
\hline 5 & $43,000 \pm 500$ & $5.95 \pm 0.50$ & 6.23 & $5.78 \pm 1.29$ & 3.60 & 0.60 & 0.60 \\
\hline 6 & $36,000 \pm 200$ & $6.11 \pm 0.74$ & 7.70 & $6.77 \pm 0.21$ & 5.02 & 0.74 & 0.83 \\
\hline 7 & $29,000 \pm 200$ & $5.03 \pm 0.60$ & 7.89 & $5.47 \pm 1.50$ & 5.00 & 0.76 & 0.83 \\
\hline 8 & $20,000 \pm 200$ & $5.19 \pm 0.90$ & 11.75 & $3.80 \pm 1.15$ & 5.12 & 1.14 & 0.85 \\
\hline $\mathrm{Hb}$ & $16,500 \pm 100$ & $4.52 \pm 1.37$ & & $4.03 \pm 0.45$ & & & \\
\hline $\begin{array}{l}\text { Glycopro- } \\
\text { teins }\end{array}$ & & $\begin{array}{c}\% \text { of } \\
\text { stained } \mathrm{CHO}\end{array}$ & & $\begin{array}{c}\% \text { of } \\
\text { stained } \mathrm{CHO}\end{array}$ & & & \\
\hline PAS-1 & $83,000 \S$ & $44.40 \pm 2.59$ & & $45.98 \pm 2.40$ & & & \\
\hline & & & 14.20 & & 8.50 & & \\
\hline PAS-2 & $25,000 \S$ & $31.10 \pm 3.54$ & & $27.87 \pm 2.36$ & $(2.8)$ & 1.37 & 1.37 \\
\hline PAS-3 & $45,000 \S$ & $12.90 \pm 4.33$ & & $13.06 \pm 6.24$ & & & \\
\hline PAS-4 & & $11.60 \pm 1.35$ & & $13.03 \pm 1.38$ & & & \\
\hline
\end{tabular}

* Calculated assuming $7.5 \times 10^{-13} \mathrm{~g}$ protein/ghost.

$\dagger$ Calculated assuming $4.5 \times 10^{-13} \mathrm{~g}$ protein/ghost.

$\ddagger$ Includes bands 2.1 and 2.2 ; hence, may be overestimated.

$\S$ Not determined in this study; assumed from Annu. Rev. Biochem. 45:667, 1976. Parenthetic entry is the per cent protein stained in the glycoprotein (Ref. 34). 
phosphatidylcholine and phosphatidylethanolamine in fetal cells. Polyacrylamide gel electrophoresis of ghosts showed similar qualitative and quantitative protein and glycoprotein bands except for the distinct appearance of bands 4.5 and 8 in the fetal ghosts. No variation in the electrophoretic mobility of fetal ghost proteins in the SDS-gels, which might suggest different molecular sizes, could be discerned. Nonetheless, individual protein species may have different primary structures and hence carry different charges. In this regard, it is noteworthy that Kohler et al. (18) have shown differences in the amino acid composition and antigenicity of the cytoplasmic fragment of band 3 from ghosts of different individuals suggesting genetic polymorphism. The PAS-staining bands (glycoproteins) were also identical in the fetal and adult cells, supporting other studies (24) in which the electrophoretic mobility of fetal and adult red cells and also the concentration of $N$-acetylneuraminic acid were similar. Quantitative densitometry of the gels and calculations of the number of total polypeptides per ghost showed that fetal ghosts contain greater numbers of polypeptides than adult erythrocyte ghosts. When the molar ratios of the individual protein bands per ghost were expressed relative to band 3, the most abundant protein, the ratios were the same for most of the polypeptides in both fetal and adult ghosts, except for bands 4.5 and 8 , which are greater in fetal ghosts. The increased membrane hemoglobin of fetal cells indicate greater difficulty in removing hemoglobin by osmotic lysis of fetal cells, perhaps due to greater affinity of fetal hemoglobin to the cytoplasmic half of the bilayer. This observation also reflects possible inherent structural difference between fetal and adult membrane which would require further investigation. These results suggest that macromolecular assembly of proteins and lipids in the fluid mosaic complex of fetal erythrocyte membranes has unique characteristics that are reflected in the ultrastructural and membrane biochemistry. It is therefore interesting to note that concanavalin A receptors in the membranes of human fetal erythrocytes show a restricted degree of lateral mobility, whereas the adult erythrocyte membrane receptors are essentially immobile (33). These membrane characteristics probably influence the functional properties of the membrane proteins, and may explain some of the reported features of fetal erythrocytes.

Acknowledgments. The authors are grateful to Drs. Marie M. Cassidy and Richard Meusing for their interest and encouragement during this study and valuable suggestions on the manuscript and to Emma Humphrey for her technical assistance. The authors are also grateful to Dr. Ron S. Weinstein at Rush Medical College, Chicago, for reviewing the manuscript and making valuable suggestions.

\section{REFERENCES}

1. Abdell LL, Levey BB, Brodie LL, Kendall FE 1952 Simplified method for the estimation of total cholesterol in serum and demonstration of its specificity. J Biol Chem 195:357

2. Bartlet GR 1959 Phosphorus assay in column chromatography. J Biol Chem 234:466

3. Barton TC, Brown DAJ 1964 Water permeability of the fetal erythrocyte. J Gen Physiol 47:839

4. Blanton PL, Martin J, Haberman S 1968 Pinocytotic response of circulating erythrocytes to specific blood grouping antibodies. J Cell Biol 37:716

5. Canham PB, Burton AC 1968 Distribution of size and shape in populations of normal human red cells. Circ Res 22:405

6. Canon, USA, Inc 1972 Statistics Library 197P-11 Programs

7. Davis BJ 1964 Disc electrophoresis. II. Method and application to human serum proteins. Ann NY Acad Sci 121:404

8. Dodge JT, Mitchell C, Hanahan DJ 1963 The preparation and chemical characteristics of hemoglobin-free ghosts of erythrocytes. Arch Biochem
Biophys 100:119

9. Evans E, Fung Y 1972 Improved measurements of the erythrocyte geometry. Microvasc Res 4:335

10. Fairbanks G, Steck TL, Wallach DFH 1971 Electrophoretic analysis of the major polypeptides of the human erythrocyte membrane. Biochemistry 10:2606

11. Folch J, Lees M, Sloan Stanley GH 1957 A simplified method for the isolation and purification of total lipids from animal tissues. J Biol Chem 226:497

12. Gercken G, Tiling T, Brockmann U, Schroter W 1972 Fatty acid composition of phospholipids in erythrocytes of adult, normal newborn infants and neonates with $\mathrm{Rh}$ erythroblastosis. Pediatr Res 6:487

13. Gross RT, Schoeder EA, Brounstein O 1963 Energy metabolism in erythrocytes of premature infants compared to full term newborn infants and adults. Blood 21:755

14. Haberman S, Blanton P, Martin J 1967 Some observations on the ABO antigen sites of the erythrocyte membranes of adults and newborn infants. J Immunol 98:150

15. Hasty DL, Hay ED 1977 Freeze-fracture studies of the developing cell surface. I. Plasmalemma of the corneal fibroblast. J Cell Biol 72:667

16. Holroyde CP, Oski FA, Gardner FA 1969 The "pocked" erythrocyte. Red cell surface alterations in reticuloendothelial immaturity of the neonate. $\mathrm{N}$ Engl J Med 281:516

17. Kelley RO, Skipper BE 1977 Development of the aging cell surface. Variations in the distribution of intramembrane particles with progressive age of human diploid fibroblasts. J Ultrastruct Res 59:113

18. Kohler H, Singh M, Steck TL 1978 Genetic polymorphism in the cytoplasmic domain of Band 3. J Supramol Struct Suppl 2:211

19. Kurantsin-Mills J, Lessin LS 1978 Ultrastructural and deformability characteristics of human fetal erythrocytes. In: Proceedings of the XVII Congress of the International Society for Hematology, Paris. Abstracts. p 561

20. Kurantsin-Mills J, Lessin LS, Brown EH 1978 Ultrastructural studies of human neonatal erythrocytes. Fed Proc 37:910

21. Lessin LS 1972 Membrane ultrastructure of normal, sickled and Heinzbody erythrocytes by freeze-etching. Nouv Rev Fr Hematol 12:871

22. Lessin LS, Jensen WN, Ponder E 1969 Molecular mechanism of hemolytic anemia in homozygous hemoglobin C disease. J Exp Med 130:443

23. Lowry OH, Rosebrough NJ, Farr AL, Randall RJ 1951 Protein measurement with the Folin phenol reagent. J Biol Chem 193:265

24. Lunar SJ, Szklarek D 1975 Comparison of electrophoretic mobility and membrane sialic acid content of erythrocytes from adult and umbilical cord blood. Pediatr Res 9:583

25. McNutt NS 1977 Freeze-fracture techniques and applications to the structural analysis of the mammalian plasma membrane. In: Poste G, Nicolson GI (eds) Dynamic Aspects of Cell Surface Organization. Elsevier/North-Holland Biomedical Press, Amsterdam, p 75

26. Mollison PL 1967 Blood Transfusion in Clinical Medicine. Blackwell, Oxford, p 275

27. Moor H, Muhlethaler K 1963 Fine structure in frozen-etched yeast cells. J Cell Biol 17:609

28. Moore TJ 1968 Glycerol permeability of human fetal and adult erythrocytes and of model membrane. J Lipid Res 9:642

29. Oski FA, Komazawa M 1975 Metabolism of the erythrocyte in the newborn infant. Semin Hematol 12:209

30. Oski FA, Schwartz E 1972 Hematology of the newborn. In: Williams WJ, Bentler E, Erslev AJ, Rundles RW (eds) Hematology. McGraw-Hill, New York, p 52

31. Pinto Da Silva P, Moss PS, Fundenberg HH 1973 Anionic sites on the membrane intercalated particles of human erythrocyte ghost membranes. Freeze-etch localization. Exp Cell Res 81:127

32. Rose HG, Oklander J 1965 Improved procedure for the extraction of lipids from human erythrocytes. J Lipid Res 6:428

33. Schekman R, Singer SJ 1976 Clustering and endocytosis of membrane receptors can be induced in mature erythrocytes of neonatal but not adult humans. Proc Natl Acad Sci USA 73:4075

34. Steck TL 1974 The organization of proteins in the human red blood cell membrane. A review. J Cell Biol 62:1

35. Tsang WCO 1975 The size and shape of human red blood cells. M.Sc. thesis University of California, San Diego

36. Weed RI, LaCelle PL, Merrill EW 1969 Metabolic dependence of red cell deformability. J Clin Invest 48:795

37. Weed RI, Reed CF, Berg G 1963 Is hemoglobin an essential structural component of human erythrocyte membranes? J Clin Invest 42:581

38. Weinstein RS 1974 The morphology of adult red cells. In: Surgenor DM (ed) The Red Blood Cell. Academic Press, New York, vol 1, p 213

39. Weinstein RS, Kohdadad JK, Steck TL 1978 Ultrastructural characterization of proteins at the natural surfaces of the red cell membrane. In: Bower CJ (ed) The Red Cell. Alan R Liss, New York, p 413

40. Willison JHM 1975 The relationship of plastic deformation in freeze-etching to the orientation of a protein particle. J Microsc 105:81

41. Zipursky A 1965 The erythrocyte of the newborn infant. Semin Hematol 2:167 